Volume 14 Issue 3 Year: 2017

\title{
Determining the functional autonomy level of preoperative elderly patients: A Turkish case study
}

\author{
Nevra Kalkan ${ }^{1}$ \\ Ayişe Karada $\breve{g}^{2}$
}

\begin{abstract}
Purpose: This study was conducted to determine the functional autonomy level of preoperative elderly patients.

Method and materials: In this descriptive and cross-sectional study, the statistical sample comprised 153 preoperative elderly patients who were hospitalized at a university hospital general surgery, neurosurgery, urological, and orthopaedic clinics in Ankara. Data were collected using a personal information form, which was based on the researcher's work and the Functional Autonomy Measurement System. Data were obtained through face-to-face interviews conducted between October 1 and December 31, 2012.

Results: Patients' total scale median score was -4.5 (min:-60, max:0), activities of daily living subscale median score was -3.5 (min:-53, max:0), communication subscale median score was 0.0 (min:-4, max:0), and mental functions subscale median score was -1.0 (min:-3, max:0). The factors affecting the level of functional independence the most were as follows (in order): using walking aids, polypharmacy, education status, nutrition status, and participation in social activities. While use of walking aids and polypharmacy have the most effect on decrease in functional independence level; primary school and higher education, regular nutritional status and participation in social activities have the most effect on increase in functional independence level. Conclusions: In this study, the functional independence level of the elderly patients was on the border of the maximal scale score.
\end{abstract}

Keywords: elderly patient; functional autonomy; functional independence; preoperative; nursing.

\section{Introduction}

Technological and scientific developments in the field of medicine, disease prevention, early stage treatment through improved diagnosis and treatment means, educational advances, and increased living standards have gradually increased the proportion of the elderly population within the total population (Ucuzal \& Akyolcu, 2008: 120; World Health Organization [WHO], 2002).

WHO (2002) reported that the worldwide elderly population will be 1.2 billion by the year 2025 and 2 billion by 2050, with 80\% living in developing countries. Turkey is one of the developing countries undergoing a rapid aging process. According to periodic censuses, the elderly population comprised $4.2 \%$ of the total population in 1985, increasing to $4.7 \%$ in $1995,6.3 \%$ in 2005, 7.3\% in 2011, and 7.7\% in 2013 (Beğer \& Yavuzer, 2012: 2; Turkish Statistical Institute,

\footnotetext{
1 Ms.N., Research Assistant, and $\mathrm{PhD}$ student in surgical nursing department in Gazi University, nevra.demir@hotmail.com

2 Prof. Dr., Koç University, School of Nursing, ayisekaradag@gmail.com
} 
Kalkan, N., \& Karadağ, A. (2017). Determining the functional autonomy level of preoperative elderly patients: A Turkish case study. Journal of Human Sciences, 14(3), 2827-2838. doi:10.14687/jhs.v14i3.4836

2014). According to population projections, this rate will increase to $10.2 \%$ in 2025 and $20.8 \%$ in 2050 (Turkish Statistical Institute, 2014).

The increase in the elderly population means that the number of elderly individuals undergoing operations will gradually increase (Oztürk, Erk1lıç, Dal, Gümüş, \& Kanbak, 2010: 40). Asouhidou et al. (2009) reported that $24 \%$ of the world's population will be aged over 65 years by 2040 and that probably half will undergo a surgical intervention. Oztürk et al.'s (2010: 41) study in Turkey, which examined anaesthetic and surgical methods for patients aged 65 years and older, determined that among the 12.871 patients who had undergone an operation in one year, 1.910 $(15 \%)$ were aged 65 years and older.

Despite surgical and anaesthetic developments and advances, undergoing an operation is still a common cause of mortality and morbidity among elderly individuals (Monarch \& Wren, 2004: 379). Due to the physiological and psychosocial changes that occur alongside aging and chronic diseases, homeostasis deteriorates more easily, the response to surgical stress and quality of life decreases, and the risk of postoperative complications increases (Finlayson \& Birkmeyer, 2009; Hacker, Zimmerman, \& Burgener, 2014). This leads to a decrease in tolerance levels for cases requiring surgical treatment in elderly individuals (Finlayson \& Birkmeyer, 2009; Gabeau \& Rosenthal, 2001; Totur \& Korkmaz, 2011: 62).

On the other hand, the literature indicates that being of advanced age is not a negative factor per se in terms of surgical risk and that the functional independence level of elderly patients is more important than their chronological age (Totur \& Korkmaz, 2011: 62). Elderly individuals have decreased functional independence during the preoperative period and experience more difficulties in performing activities of daily living (ADL) in the postoperative period (Finlayson \& Birkmeyer, 2009). Boltz et al. (2012: 272) reported that a majority of patients aged 65 and over lost more than $50 \%$ of their ability to perform their ADL post-hospitalization when they were previously able to perform all their ADL. Tuna and Çelik (2014: 573) performed a randomized controlled study that investigated the possible effect of discharge training and counselling on the functional autonomy and post-discharge problems of elderly patients undergoing coronary artery bypass graft surgery in Turkey $(n=36)$. Using the Functional Autonomy Measurement System (SMAF), they found that the postoperative functional autonomy levels of the study group and the control group were $-8.8 \pm 4.5$ and $-13.5 \pm 8.5$, respectively.

The loss of functional independence in elderly individuals or the failure to notice such loss leads to an increase in the hospitalization period, delayed mobilization, a delayed return to ADL, a decrease in quality of life, and increased healthcare costs related to these factors (Finlayson \& Birkmeyer, 2009; Hébert, Guilbault, Desrosiers, \& Dubuc, 2001: 141). Therefore, determining the functional independence level of elderly patients admitted to the hospital should be a routine part of preoperative assessment (Gabeau \& Rosenthal, 2001).

One of the most important factors influencing the success of surgical interventions is the quality and performance of preoperative and postoperative care (Karabulut \& Çetinkaya, 2011: 14). Thus, nurses working in surgical clinics must be aware of physiological and psychosocial changes that occur as a result of the aging process, and they must develop a nursing care plan for elderly patients in the preoperative period by collecting information on their personal characteristics, living environment, medication, chronic diseases, nutritional status, risk of falling, and surgical intervention history (Monarch \& Wren, 2004; Totur \& Korkmaz, 2011). The preoperative and postoperative implementation of the care, planned in line with the requirements of each elderly individual, will reduce the patient's risk of developing complications, loss of functional independence, and duration of hospital stay (Çeçen \& Özbayır, 2010: 12). However, due to the heavy workload of nurses working in surgical clinics in Turkey, adequate time cannot be spared for each patient, and difficulties are experienced in patient care (Karabulut \& Çetinkaya, 2011: 15). This causes the care provided to elderly patients to be similar to the care provided to individuals in other age groups. 
Kalkan, N., \& Karadağ, A. (2017). Determining the functional autonomy level of preoperative elderly patients: A Turkish case study. Journal of Human Sciences, 14(3), 2827-2838. doi:10.14687/jhs.v14i3.4836

\section{Purpose}

This study was conducted to determine the functional independence level of elderly patients admitted to surgical clinics to undergo an operation and to identify the factors influencing their level of functional independence. It is hoped that the study's results will contribute to the establishment of procedures that evaluate the level of functional independence of elderly individuals in nursing care procedures and to the relevant literature.

\section{Method and material}

\subsection{Population and sample selection}

The study's scope included individuals aged 65 and older who were admitted to the surgical clinic of a 1100-bed university hospital to undergo an operation between September 1, 2012 and December 31, 2012. A total of 256 patients underwent an operation during the study period. However, because some unevaluated patients were directly transferred to the operating room from the polyclinic without being admitted to the clinic $(n=72)$ and some patients chose not to participate in the study ( $\mathrm{n}=31)$, the study was completed with 153 patients (participation rate $=60 \%$ ). The Number Cruncher Statistical System (NCSS) and Power Analysis and Sample Size (PASS) 11.0 (Utah, USA) were used to determine the study's power, and a two-unit change was considered in the mean total scale score for those who participated in the study; the power was determined to be $80 \%(\alpha=0.05)$.

\subsection{Type of study}

The study was descriptive and cross-sectional study.

\subsection{Data collection}

Data were collected using a personal information form and SMAF via face-to-face interviews with patients performed by the researcher. The personal information form, which was based on the existing literature, was prepared by the researcher (Cingil \& Bodur, 2008; Çeçen \& Özbayır, 2010; Hacıhasanoğlu, Yıldırım, \& Karakurt, 2012; Olgun, Aslan, Yücel, Öntürk, \& Laçin, 2013; Ucuzal \& Akyolcu, 2008; Tuna \& Çelik, 2014), and the opinions of three experts in the field were consulted. This form featured 34 questions related to the socio-demographic characteristics of the elderly individuals (age, gender, body mass index, marital status, persons they lived with, educational status, employment status, and economic status), health condition characteristics (chronic diseases, constantly used medication, previous operations, smoking and drinking alcohol, status of sleeping, status of regular exercise, status of forgetfulness, and urinary and faecal incontinence), nutritional status (number of meals in a day, daily fluid intake, special diet, status of adhering to the special diet, and dental prosthesis use), use of aids (prosthesis/orthosis and using walking aids, glasses, and hearing aids), fall history (post-fall fracture history and status of abstaining from walking due to the fear of falling), and status of social activities.

The SMAF (Hébert et al., 1984) is based on the concepts of deficiency and disability defined in the WHO's International Classification of Impairments, Disabilities, and Handicaps (ICIDH) (Hébert, Guilbault, Desrosiers, \& Dubuc, 2001; Tuna \& Çelik, 2012). This scale determines whether an elderly individual is at risk of losing functional independence. Tuna \& Çelik (2012) conducted a validity and reliability study of this scale for Turkey. The adapted scale consists of items related to various subscales, such as ADL (19 functions), communication ( 3 functions), and mental functions ( 3 functions). Cronbach's alpha coefficient value was 0.95 for the disability part of the adapted Turkish scale. The following were evaluated: in the ADL subscale, the functions of eating, washing, dressing, grooming, urinary continence, faecal continence, using the bathroom, transfers, walking inside, using the stairs, walking outside, cleaning the house, preparing meals, shopping, doing the laundry, using the telephone, using public transportation, taking medications, 
Kalkan, N., \& Karadağ, A. (2017). Determining the functional autonomy level of preoperative elderly patients: A Turkish case study. Journal of Human Sciences, 14(3), 2827-2838. doi:10.14687/jhs.v14i3.4836

and managing the budget; in the communication subscale, the functions of seeing, hearing, and speaking; and in the mental functions subscale, the functions of memory, understanding, and judgment.

For each item, the disability is scored on a 5-point scale: 0 (independent), [-0.5 (with difficulty), -1 (needs supervision), -2 (needs help)] and -3 (dependent). The total disability score of the scale is obtained through the sum of all function scores. The SMAF ranges from -75 (lowest) to 0 (highest). If the total score is less than -5 , the elderly individual is at risk of losing functional independence. The ADL subscale ranges from -57 (lowest) to 0 (highest). The communication subscale ranges from -9 (lowest) to 0 (highest). The mental functions subscale ranges from -9 (lowest) to 0 (highest) (Tuna \& Çelik, 2012). Cronbach's alpha coefficient value was 0.91 in our study.

\subsection{Research ethics}

Written permission was obtained from the department heads of the surgical clinics included in the study. Ethics committee approval was received from the Non-Interventional Clinical Research Ethics Committee (25901600-2706), and written consent was received from the study's participants.

\subsection{Evaluation of data}

SPSS Statistics for Windows version 16.0 (SPSS Inc., Chicago, Illinois, USA) was used for the data evaluation. Number and percentile calculations were used for statistical analysis. As parametric test assumptions could not be ensured, the Mann-Whitney U Test was used for the twogroup comparison of numerical data, and the Kruskal-Wallis Test was used for the comparison of more than two groups. Where there were differences in the comparison of more than two groups, the Mann-Whitney U Test with Bonferroni correction was used to perform paired comparisons. The relationship between two numeric variables was evaluated using the Spearman's rank correlation coefficient because the variables did not demonstrate a normal distribution. The overall statistical level of significance in the study was set at $\mathrm{p}<0.05$. The chi-square test was used when determining the independent variables to be included in the multivariable logistic regression analysis. After commencing the procedure for selecting the variables with a single variable logistic regression analysis, the variables determined according to the $\mathrm{p}<0.20$ level of significance were included in the logistic regression.

\section{Results}

The participants' mean age was $72.64 \pm 6.52 ; 54.9 \%$ were males, $68.6 \%$ were married, $44.4 \%$ lived with their spouse, $34.6 \%$ were primary school graduates, $93.5 \%$ did not work, $64.1 \%$ expressed a medium-level economic status; $76.5 \%$ had at least one chronic disease; and $28.8 \%$ took multiple medications.

The patients' total scale median score was -4.5 ( $\min =-60, \max =0)$, activity of daily living (ADL) subscale median score was -3.5 ( $\min =-53$, $\max =0)$, communication subscale median score was $0.0(\min =-4, \max =0)$, and mental functions subscale median score was $-1.0(\min =-3, \max =0)$ (Table 1). The number of patients with a total scale score of 0 (completely independent) was 3 , and no patient received a score of -75 (completely dependent). The following proportions of the study's patients were found to be completely independent: 7.2\% $(n=11)$ as per the ADL subscale, $51.6 \%$ $(n=79)$ as per the communication subscale, and $46.4 \%(n=71)$ as per the mental functions subscale. 
Kalkan, N., \& Karadağ, A. (2017). Determining the functional autonomy level of preoperative elderly patients: A Turkish case study. Journal of Human Sciences, 14(3), 2827-2838. doi:10.14687/jhs.v14i3.4836

Table 1. Distribution of the mean functional independence scores of patients $(n=153)$

\begin{tabular}{lccc} 
Subscales of SMAF & Median & Min. & Max. \\
\hline Activity of daily living & -3.5 & -53 & 0 \\
\hline Communication & 0.0 & -4 & 0 \\
\hline Mental functions & -1.0 & -3 & 0 \\
\hline General SMAF score & -4.5 & -60 & 0 \\
\hline
\end{tabular}

Patients' median functional independence scores according to their sociodemographic characteristics demonstrated that their age group, gender, educational status, and persons with whom they lived were statistically significant factors $(\mathrm{p}<0.05)($ Table 2$)$.

Table 2. Median functional independence scores of patients according to their sociodemographic characteristics $(n=153)$

\begin{tabular}{|c|c|c|c|c|}
\hline $\begin{array}{c}\text { Socio- } \\
\text { demographic } \\
\text { characteristics }\end{array}$ & $\begin{array}{c}\text { ADL } \\
\text { Median } \\
\text { (min.-max.) }\end{array}$ & $\begin{array}{c}\text { Communication } \\
\text { Median } \\
\text { (min.-max.) }\end{array}$ & $\begin{array}{c}\text { Mental } \\
\text { Functions } \\
\text { Median } \\
\text { (min.-max.) }\end{array}$ & $\begin{array}{c}\text { General SMAF } \\
\text { Score } \\
\text { Median } \\
\text { (min.-max.) }\end{array}$ \\
\hline \multicolumn{5}{|l|}{ Age groups* } \\
\hline $65-74$ years old & $-2.5(-43-0)$ & $0.0(-3-0)$ & $0.0(-2-0)$ & $-3.25(-43-0)$ \\
\hline $75-84$ years old & $-5.0(-31-0)$ & $-1.0(-2-0)$ & $-1.0(-2-0)$ & $-5.75(-33--0.5)$ \\
\hline 85 years and & $-19.0(-53--5)$ & $-1.0(-4-0)$ & $-1.0(-3-0)$ & $-20.0(-60--8)$ \\
\hline older & $\mathrm{p}=\mathbf{0 . 0 0 0}$ & $\mathrm{p}=\mathbf{0 . 0 0 0}$ & $\mathrm{p}=0.117$ & $\mathrm{p}=\mathbf{0 . 0 0 0}$ \\
\hline \multicolumn{5}{|l|}{ Gender** } \\
\hline Female & $-5.5(-53-0)$ & $0.0(-4-0)$ & $-1.0(-3-0)$ & $-7.0(-60--0.5)$ \\
\hline \multirow[t]{2}{*}{ Male } & $-2.5(-31-0)$ & $0.0(-3-0)$ & $0.0(-2-0)$ & $-3.5(-33-0)$ \\
\hline & $\mathrm{p}=0.000$ & $\mathrm{p}=\mathbf{0 . 0 1 0}$ & $\mathrm{p}=0.197$ & $\mathrm{p}=0.000$ \\
\hline \multicolumn{5}{|c|}{ Educational status* } \\
\hline Illiterate & $-8.5(-53-0)$ & $0.0(-4-0)$ & $-1.0(-3-0)$ & $-9.5(-60-0)$ \\
\hline Literate & $-5.5(-24--0.5)$ & $-1.0(-2-0)$ & $-1.0(-1-0)$ & $-6.5(-25-2)$ \\
\hline Primary School & $-2.5(-43-0)$ & $0.0(-3-0)$ & $-1.0(-1-0)$ & $-3.5(-43--0.5)$ \\
\hline Middle School & $-2.0(-17-0)$ & $0.0(-3-0)$ & $0.0(-2-0)$ & $-3.5(-4--0.5)$ \\
\hline High School & $-2.0(-25.5-0)$ & $-1.0(-2-0)$ & $0.0(-2-0)$ & $-3.25(-27.5-0)$ \\
\hline \multirow{2}{*}{ University } & $-2.0(-15.5-0)$ & $0.0(-3-0)$ & $0.0(-1-0)$ & $-2.5(-16.5--1)$ \\
\hline & $\mathrm{p}=0.000$ & $\mathrm{p}=0.872$ & $\mathrm{p}=0.248$ & $\mathrm{p}=0.000$ \\
\hline \multicolumn{5}{|c|}{ Perceived Economic Status* } \\
\hline Good & $-2.75(-53-0)$ & $-1.0(-4-0)$ & $0.0(-3-0)$ & $-3.75(-60-0)$ \\
\hline Medium & $-3.5(-34-0)$ & $0.0(-3-0)$ & $-1.0(-2-0)$ & $-5.0(-35-0)$ \\
\hline \multirow[t]{2}{*}{$\mathrm{Bad}$} & $-7.5(-43-0)$ & $0.0(-2-0)$ & $0.0(-2-0)$ & $-9.5(-43--1)$ \\
\hline & $\mathrm{p}=0.046$ & $\mathrm{p}=0.342$ & $p=0.246$ & $\mathrm{p}=0.056$ \\
\hline \multicolumn{5}{|c|}{ Persons they live with* } \\
\hline Alone & $-4.5(-26--0.5)$ & $0.0(-2-0)$ & $-1.0(-1-0)$ & $-5.5(27.5--1)$ \\
\hline Spouse & $-2.5(-23-0)$ & $-1.0(-3-0)$ & $-1.0(-2-0)$ & $-4.0(-26-0)$ \\
\hline Spouse and children & $-3.0(-24-0)$ & $-0.5(-3-0)$ & $-0.5(-1-0)$ & $-3.75(-25-0)$ \\
\hline \multirow[t]{2}{*}{ Children } & $-10.0(-53-0)$ & $-0.0(-4-0)$ & $-1.0(-3-0)$ & $-9.5(-60--0.5)$ \\
\hline & $\mathrm{p}=0.000$ & $\mathrm{p}=0.193$ & $\mathrm{p}=0.828$ & $\mathrm{p}=0.001$ \\
\hline
\end{tabular}

* The Kruskal Wallis Test was applied.

** The Mann Whitney U Test was applied. 
Kalkan, N., \& Karadağ, A. (2017). Determining the functional autonomy level of preoperative elderly patients: A Turkish case study. Journal of Human Sciences, 14(3), 2827-2838. doi:10.14687/jhs.v14i3.4836

Patients' median functional independence scores according to their health conditions and ADL demonstrated that chronic disease, polypharmacy, problems with forgetfulness, regular nutritional status, urinary incontinence, status of regular exercise, participation in social activities, fall history, and use of walking aids were statistically significant factors $(\mathrm{p}<0.05)$ (Table 3).

Table 3. Median functional independence scores of patients according to their health conditions and ADL $(n=153)$

\begin{tabular}{|c|c|c|c|c|}
\hline $\begin{array}{l}\text { Health } \\
\text { status }\end{array}$ & $\begin{array}{c}\text { ADL } \\
\text { Median } \\
\text { (min.-max.) }\end{array}$ & $\begin{array}{c}\text { Communication } \\
\text { Median } \\
\text { (min.-max.) }\end{array}$ & $\begin{array}{c}\text { Mental } \\
\text { Functions } \\
\text { Median } \\
\text { (min.-max.) }\end{array}$ & $\begin{array}{c}\text { General SMAF } \\
\text { Score } \\
\text { Median } \\
\text { (min.-max.) }\end{array}$ \\
\hline \multicolumn{5}{|c|}{ Chronic Disease** } \\
\hline Yes & $-4.0(-53-0)$ & $0.0(-4-0)$ & $-1.0(-3-0)$ & $-5.5(-60-0)$ \\
\hline \multirow[t]{2}{*}{ No } & $-2.25(-20-0)$ & $0.0(-2-0)$ & $-0.0(-1-0)$ & $-3.25(-20-0)$ \\
\hline & $\mathrm{p}=0.048$ & $p=0.699$ & $\mathrm{p}=\mathbf{0 . 0 3 4}$ & $\mathrm{p}=0.036$ \\
\hline \multicolumn{5}{|c|}{ Polypharmacy ** } \\
\hline Yes & $-5.5(-31-0)$ & $-1.0(-3-0)$ & $-1.0(-2-0)$ & $-7.5(-33-0)$ \\
\hline \multirow[t]{2}{*}{ No } & $-3.0(-53-0)$ & $0.0(-4-0)$ & $0.0(-3-0)$ & $-4.0(-60-0)$ \\
\hline & $\mathrm{p}=0.008$ & $\mathrm{p}=0.305$ & $\mathrm{p}=0.095$ & $\mathrm{p}=0.005$ \\
\hline \multicolumn{5}{|c|}{ Problem of forgetfulness** } \\
\hline Yes & $-4.5(-53-0)$ & $-1.0(-4-0)$ & $-1.0(-3-0)$ & $-5.5(-60--1)$ \\
\hline \multirow[t]{2}{*}{ No } & $-3.0(-43--0)$ & $0.0(-3-0)$ & $0.0(-1-0)$ & $-4.0(-43-0)$ \\
\hline & $\mathrm{p}=0.613$ & $\mathrm{p}=0.340$ & $\mathrm{p}=0000$ & $\mathrm{p}=\mathbf{0 . 0 4 2}$ \\
\hline \multicolumn{5}{|c|}{ Regular nutritional status** } \\
\hline Yes & $-2.5(-29-0)$ & $0.0(-3-0)$ & $-1.0(-2-0)$ & $-3.5(-30-0)$ \\
\hline \multirow[t]{2}{*}{ No } & $-5.5(-53-0)$ & $-1.0(-4-0)$ & $-1.0(-3-0)$ & $-8.5(-60--1)$ \\
\hline & $\mathrm{p}=0.000$ & $\mathrm{p}=0.046$ & $\mathrm{p}=0.617$ & $\mathrm{p}=0.000$ \\
\hline \multicolumn{5}{|c|}{ Urinary incontinence $* *$} \\
\hline Yes & $-5.5(-53--0.5)$ & $-1.0(-4-0)$ & $-1.0(-3-0)$ & $-7.0(-60--1)$ \\
\hline \multirow[t]{2}{*}{ No } & $-3.0(-43-0)$ & $0.0(-3-0)$ & $0.0(-2-0)$ & $-40(-43-0)$ \\
\hline & $\mathrm{p}=.004$ & $\mathrm{p}=0.339$ & $\mathrm{p}=0.126$ & $\mathrm{p}=\mathbf{0 . 0 0 8}$ \\
\hline \multicolumn{5}{|c|}{ Status of regular exercise** } \\
\hline Yes & $-1.75(-12.5-0)$ & $0.0(-2-0)$ & $0.0(-1-0)$ & $-2.5(-12.5--0.5)$ \\
\hline \multirow[t]{2}{*}{ No } & $-4.0(-53-0)$ & $0.0(-4-0)$ & $-1.0(-3-0)$ & $-5.0(-60-0)$ \\
\hline & $\mathrm{p}=0.009$ & $\mathrm{p}=0.622$ & $\mathrm{p}=0.346$ & $\mathrm{p}=0.007$ \\
\hline \multicolumn{5}{|c|}{ Participation in social activities $* *$} \\
\hline Yes & $-2.0(-19-0)$ & $0.0(-3-0)$ & $-1.0(-2-0)$ & $-3.0(-20-0)$ \\
\hline \multirow[t]{2}{*}{ No } & $-6.5(-53-0)$ & $-1.0(-4-0)$ & $-1.0(-3-0)$ & $-7.5(-60-0)$ \\
\hline & $\mathrm{p}=0.000$ & $\mathrm{p}=0.049$ & $\mathrm{p}=0.363$ & $\mathrm{p}=0.000$ \\
\hline \multicolumn{5}{|c|}{ Fall History** } \\
\hline Yes & $-5.0(-53-0)$ & $0.0(-4-0)$ & $-1.0(-3-0)$ & $-7.0(-60-0)$ \\
\hline \multirow[t]{2}{*}{ No } & $-3.0(-43-0)$ & $-1.0(-3-0)$ & $-1.0(-2-0)$ & $-4.25(-43-0)$ \\
\hline & $\mathrm{p}=0.022$ & $p=0.134$ & $\mathrm{p}=0.617$ & $\mathrm{p}=0.038$ \\
\hline \multicolumn{5}{|c|}{ Use of walking aids** } \\
\hline Yes & $-8.5(-53--0.5)$ & $-1.0(-4-0)$ & $-1.0(-3-0)$ & $-10.5(-60--0.5)$ \\
\hline \multirow[t]{2}{*}{ No } & $-2.5(-43-0)$ & $0.0(-3-0)$ & $-1.0(-2-0)$ & $-3.5(-43-0)$ \\
\hline & $\mathrm{p}=0.000$ & $\mathrm{p}=0.371$ & $p=0.905$ & $\mathrm{p}=0.000$ \\
\hline
\end{tabular}

** The Mann Whitney U Test was applied.

In the current study, the factors affecting the level of functional independence the most were as follows (in order): using aids, polypharmacy, education status, nutrition status, and 
Kalkan, N., \& Karadağ, A. (2017). Determining the functional autonomy level of preoperative elderly patients: A Turkish case study. Journal of Human Sciences, 14(3), 2827-2838. doi:10.14687/jhs.v14i3.4836

participation in social activities. While use of walking aids and polypharmacy have the most effect on decrease in functional independence level; primary school and higher education, regular nutritional status and participation in social activities have the most effect on increase in functional independence level. (Table 4).

Table 4. Factors influencing the level of functional independence

\begin{tabular}{|c|c|c|c|c|c|}
\hline $\begin{array}{l}\text { Independent } \\
\text { variables }\end{array}$ & $\begin{array}{c}\text { Regression } \\
\text { coefficient } \\
\text { (B) }\end{array}$ & $\begin{array}{c}\text { Standard } \\
\text { error } \\
(\mathrm{SEM})\end{array}$ & p Value & $\begin{array}{c}\text { Odds } \\
\text { Ratio } \\
\text { (Exp B) }\end{array}$ & $\begin{array}{c}95 \% \\
\text { Confidence } \\
\text { interval }\end{array}$ \\
\hline \multicolumn{6}{|l|}{ Educational } \\
\hline Status & - & - & 0.000 & - & \\
\hline Illiterate & -0.492 & 0.918 & 0.592 & 0.611 & $0.101-3.699$ \\
\hline Literate & -3.107 & 0.759 & 0.000 & 0.045 & $0.010-0.198$ \\
\hline Primary School & -2.793 & 1.049 & 0.008 & 0.062 & $0.008-0.478$ \\
\hline Middle School & -2.460 & 1.001 & 0.014 & 0.085 & $0.012-0.607$ \\
\hline High School & -2.675 & 0.999 & 0.007 & 0.069 & $0.010-0.488$ \\
\hline \multicolumn{6}{|l|}{ University } \\
\hline Polypharmacy & 1.343 & 0.551 & 0.015 & 3.832 & $1.300-11.293$ \\
\hline $\begin{array}{l}\text { Regular } \\
\text { nutritional status }\end{array}$ & -2.282 & 0.579 & 0.000 & 0.102 & $0.033-0.318$ \\
\hline $\begin{array}{l}\text { Status of using } \\
\text { walking-aid tools }\end{array}$ & 2.356 & 0.606 & 0.000 & 10.544 & $3.212-34.607$ \\
\hline $\begin{array}{l}\text { Participation in } \\
\text { social activities }\end{array}$ & -1.452 & 0.527 & 0.006 & 0.234 & $0.083-0.657$ \\
\hline
\end{tabular}

\section{Discussion}

Physiological and psychosocial change occurring together with age increase the risk that elderly individuals will lose their functional independence. Advanced age is not a negative factor per se, and functional condition is more important than chronological age in elderly patients (Totur \& Korkmaz, 2011: 62). Therefore, the evaluation of the functional condition of elderly patients is very important (Finlayson \& Birkmeyer, 2009).

In our study, the ADL subscale found that patients were most independent in the following (in order): faecal continence, eating, dressing, and grooming. The functions for which they were most dependent were managing the budget, doing the laundry, and cleaning the house. In Çeçen and Özbayır's (2010: 17) study, which investigated the ADL dependence status of elderly patients in a surgical clinic with a mean age of $73.3(n=113)$, the functions that required the most dependence were as follows (in order): paying bills, cleaning, and shopping.

The results in the existing literature vary regarding the various functional independence levels of elderly individuals living in various settings. In Hacihasanoğlu et al.'s (2012) study, which looked at loneliness in elderly individuals $(n=830)$, the level of dependence in ADL, and the influential factors, the functions that required the most dependence were using stairs, mobility, washing, and cleaning the house. Onem et al.'s (2010) study, which evaluated the ADL abilities of individuals with a mean age of 71.5 who were living in nursing homes $(n=180)$, used the Katz ADL Index to determine that washing, dressing, and using the bathroom were the functions requiring the most dependence. Arslantaş et al.'s (2009) study, which looked at the quality of life and ADL of elderly individuals living in rural areas with a mean age of $71.5(\mathrm{n}=1301)$, found that shopping, preparing meals, and using public transportation were the functions requiring the most dependence.

In this study, the mean functional independence score decreased as the age of the patient 
Kalkan, N., \& Karadağ, A. (2017). Determining the functional autonomy level of preoperative elderly patients: A Turkish case study. Journal of Human Sciences, 14(3), 2827-2838. doi:10.14687/jhs.v14i3.4836

increased (Table 2). Our findings demonstrate similarity with the results of previous studies. In King et al.'s (2002) study, 10\% of individuals aged between 65 and 69 years and 47\% of individuals aged 85 years and older were dependent in their ADL. Ulusel et al.'s (2004) study found that individuals aged 75 years and older were 2.5 times more dependent than individuals in the 65 - to 74-year-old age group.

The functional independence scores of female patients were lower than those of male patients in this study (Table 2). A higher life expectancy and more chronic diseases due to developmental processes such as fertility/menopause have been found to have a bearing on the lower level of functional independence of females compared to males (Erel \& Uygur, 2010: 41; Hacihasanoğlu, Yildırım, \& Karakurt, 2012: 65). The mean of age of the females in our study (X $=73.3)$ was higher than the mean age of the males $(\bar{X}=72.0)$, which could affect the results.

Those in the literate group had a lower level of functional independence than those in the university graduate group (Table 2). In Hacihasanoğlu et al.'s (2012: 63) study, there were no significant differences based on the level of education; there were no completely dependent individuals who were university graduates and 7 illiterate individuals who were completely dependent. Furthermore, low functional independence levels were found for individuals who selfreported a low economics status (Table 2). Therefore, a low socioeconomic level can considered to have an important bearing on functional independence (Cingil \& Bodur, 2008: 34); individuals with a high economic status have easier access to prevention, treatment, and rehabilitation services, and educated individuals have more awareness concerning their health and act accordingly (Hacıhasanoğlu, Yıldırım, \& Karakurt, 2012: 64).

Despite the change in family structures in Turkey, a large majority of elderly individuals live in the same house as their children, and their children are responsible for their care (Tezcan \& Seçkiner, 2012). In other words, elderly individuals with decreased functional independence are assisted by their children. In this study, individuals living with their children had a lower level of functional independence than other groups (Table 2). This finding can also be interpreted as a majority of elderly individuals with decreased functional independence needing to live together with family members or children assuming functions such as shopping and managing the budget, which makes elderly individuals more dependent.

The incidence of chronic diseases has increased due to the increase in life expectancy and the physiological changes occurring in old age (Olgun, Aslan, Yücel, Öntürk, \& Laçin, 2013: 76). In this study, more than two-thirds of elderly patients were found to have at least one chronic disease (Table 3). In Öztürk et al.'s (2011) study, which evaluated the functional independence condition of elderly individuals via the Functional Independence Measure $(n=100)$, having a chronic disease had an adverse effect on the level of functional independence. The problem of polypharmacy arises with chronic diseases and occurs subsequent to morbidity in the elderly. In Mizokami et al.'s (2012) 1 -year cross-sectional study $(\mathrm{n}=1768)$, they found that the mean number of diseases was $7.7 \pm 3.4$,

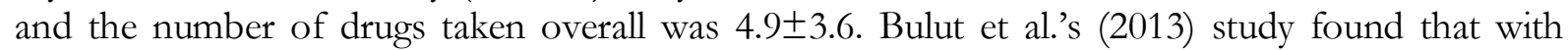
polypharmacy, there was a greater chance for confusion and adverse consequences related to the knowledge of these medications and their usage. Polypharmacy should be investigated due to the use of anaesthesia, analgesics, and medication in the surgical process, the interaction of medications used, and side effects (Çeçen \& Özbayır, 2010: 19). Patients with a chronic disease and polypharmacy were found to have a low functional independence level (Table 3).

Forgetfulness is a frequently encountered problem in people of advanced years; with age, the speed of learning and recalling starts to slow down (Atli, 2012: 24). More than half of this study's patients had a forgetfulness problem. Patients with forgetfulness stated that they forgot names and places where they put things, and they forgot to take their medicine. Forgetfulness frequently causes medicine side effects and intoxication, drug interactions, and changes in drug pharmacokinetics and pharmacodynamics in elderly individuals. Thus, nurses should determine the purpose, correct dosage, and time of each medication and the points requiring attention, and they 
Kalkan, N., \& Karadağ, A. (2017). Determining the functional autonomy level of preoperative elderly patients: A Turkish case study. Journal of Human Sciences, 14(3), 2827-2838. doi:10.14687/jhs.v14i3.4836

should provide relevant training (Özer \& Özdemir, 2009: 49). Forgetfulness can also have an adverse effect on the level of functional independence due to the resultant difficulty in performing activities such as shopping, using the telephone, managing the budget, and taking medications. The total scale median score and the mental functions subscale median score of patients with forgetfulness were lower compared to patients who did not have forgetfulness in our study (Table $3)$.

There is an interrelationship between nutritional and functional status impairment (Abd-AlAtty et al., 2012). In this study, the mean functional independence score decreased as the nutritional status of patient worsened (Table 3). Increasing age is associated with an unhealthier nutritional status, decreased food preparation, reduced appetite, dental diseases, polypharmacy, changes in metabolism, and chronic diseases (Kim et al., 2014: 18). Abd-Al-Atty et al.'s (2012: 357) study $(n=230)$ found that elderly patients with an unregular nutritional status functional independence score had poorer health.

Urinary incontinence, which a problem frequently encountered by elderly individuals, causes psychosocial problems such as sleeping disorders, social isolation, anxiety, depression, increased risk of falling, and decreased functional independence and quality of life (Çeçen \& Özbayır, 2010: 20; Varl, Aras, \& Atll, 2009). Furthermore, urinary incontinence increases the incidence of pressure ulcers and leads to incontinence-related dermatitis, deterioration in skin integrity, and infections (Ulusel, Soyer, \& Uçku, 2004: 203; Varll, Aras, \& Atl, 2009: 46).In this study, the level of functional independence of patients with urinary incontinence was found to be low (Table 3). Therefore, urinary incontinence should be evaluated in elderly individuals who will undergo an operation, and suitable interventions should be planned.

Regular exercise decreases chronic diseases and ensures the continuation of social activities (Nascimento et al., 2012: e94). The levels of independence were higher for patients undertaking regular exercise and engaging in social activities than for those who did not engage in these activities (Table 3). As elderly individuals engaging in social activities can perform functions such as walking, walking outside, using the telephone, and seeing and hearing independently, their functional independence was found to be higher.

Together with changes in sensory organs, the following increase the risk of falling: increasing medication use in the surgical process, lack of attention due to operation-related anxiety, and difficulties experienced in the capacity of sensory perception due to anaesthesia (Çeçen \& Özbayır, 2011: 18-21). Patients who had a fall history and who used walking aids had a low functional independence level (Table 3). Elders' falls may result in tissue injury, fractures, fear of falling, and a decrease in functional independence (Tunçay, Özdinçler, \& Erdinçler, 2011: 246; Demir \& Erdil, 2013: 1238). Therefore, the fall history of elders should be investigated in the early stage, with risk factors leading to falls determined and measures taken to prevent falls (Byers et al., 2008: 246).

\section{Conclusion and recommendations}

In this study, the patients' total scale median score was -4.5 , ADL subscale median score was -3.5 , communication subscale median score was 0.0 , and mental functions subscale median score was -1.0 . The number of patients with a total scale score of 0 (completely independent) was 3 , and no patient received a score of -75 (completely dependent). These results demonstrate that the patients are at the limits in terms of their functional independence levels. In this study, the factors most affecting functional independence were as follows (in order): using aids, polypharmacy, education, nutrition, and engaging in social activities. Therefore, the following are recommended: evaluations be undertaken of the level of functional independence of all preoperative elderly individuals in nursing care procedures, the SMAF be used in clinics, care protocols be developed for the purpose of improving the level of functional independence in elderly individuals, and nurses be encouraged and supported in using these protocols as information sources. 
Kalkan, N., \& Karadağ, A. (2017). Determining the functional autonomy level of preoperative elderly patients: A Turkish case study. Journal of Human Sciences, 14(3), 2827-2838. doi:10.14687/jhs.v14i3.4836

\section{References}

Abd-Al-Atty, M. F., Abou-Hashem, R. M., \& Abd Elaziz, K. M. (2012). Functional capacity of recently hospitalized elderly in relation to nutritional status. European Geriatric Medicine, 3(6), 356-359. doi.org/10.1016/j.eurger.2012.08.003

Arslantas, D., Ünsal, A., Metintas, S., Koc, F., \& Arslantas, A. (2009). Life quality and daily life activities of elderly people in rural areas, Eskişehir (Turkey). Archives of Gerontology and Geriatrics, 48(2), 127-131. doi: 10.1016/j.archger.2007.11.005.

Asouhidou, I., Asteri, T., Sountoulides, P., Natsis, K., \& Georgiadis, G. (2009). Early postoperative mortality in the elderly: a pilot study. BMC Research Notes, 2, 118. doi.org/10.1186/17560500-2-118

Atl, T. (2012). Yaşlıda unutkanlığa yaklaşım. Klinik Gelişim, 25, 24-28.

Beğer, T., \& Yavuzer, H. (2012). Yaşlllık ve yaşlllık epidemiyolojisi. Klinik Gelişim, 25, 1-3.

Boltz, M., Resnick, B., Capezuti, E., Shuluk, J., \& Secic, M. (2012). Functional decline in hospitalized older adults: can nursing make a difference? Geriatric Nursing, 33(4), 272-279. doi.org/10.1016/j.gerinurse.2012.01.008

Bozkurt, Ü. \& Yllmaz, M. (2016). The determination of functional independence and quality of life of older adults in a Nursing Home. International Journal of Caring Sciences, 9(1), 198-210.

Bulut, H., Tanrikulu, G., Dal, U., \& Kapucu, S. (2013). How much do ED patients know about medication prescribed for them on discharge? A pilot study in Turkey. Journal of Emergency Nursing, 39(3), 27-32. doi: 10.1016/j.jen.2008.12.017.

Byers, A. L., Sheeran, T., Mlodzianowski, A. E., Meyers, B. S., Nassisi, P., \& Bruce, M. L. (2008). Depression and risk for adverse falls in older home health care patients. Research in Gerontological Nursing, 1(4), 245-251. doi:10.3928/19404921-20081001-03.

Çeçen, D., \& Özbayır, T. (2010). Cerrahi kliniklerinde yatan yaşlı hastaların genel sağllk durumlarının değerlendirilmesi [Evaluation of the general health status of the geriatric patients who are treated in surgical clinics]. Ege Üniversitesi Hemsirelik Yükesekokulu Dergisi, 26(3), 11-22.

Çeçen, D., \& Özbayır, T. (2011). Cerrahi kliniklerinde yatan yaşlı hastalarda düşme riskinin belirlenmesi ve düşmeyi önlemeye yönelik yapılan girişimlerin değerlendirilmesi [Evaluation of practies related to falling prevention and determination of falling risk of elderly patients who are treated in surgical clinics]. Ege Üniversitesi Hemşirelik. Yüksekokulu Dergisi, 27(1), 1123.

Cingil, D., \& Bodur, S. (2008). Karaman il merkezinde yaşayan yaşllların bağımlllık düzeyleri, demografik ve medikal özelliklerinin incelenmesi [The investigation of demographic and medical properties and levels of dependent in activities of daily living of older adults living in Karaman]. Atatürk Üniversitesi Hemsirelik Yülksek Okulu Dergisi, 11(3), 33-39.

Demir, S.G., Erdil, F. (2013). Effectiveness of home monitoring according to the model of living in hip replacement surgery patient. Journal of Clinical Nursing, 22, 1226-1241. doi: 10.1111/jocn. 12255.

Erel, S., \& Uygur, F. (2010). Toplumda ve huzurevinde yaşayan yaşlı bireylerin fiziksel performans1 ve yaşam kalitesinin karşılaştırılması [Comparison of physical performance and quality of life of elder individuals living in the community and in nursing homes]. Firyoterapi Rebabilitasyon, 21(1), $35-42$.

Finlayson, E., \& Birkmeyer, J. D. (2009). Surgical outcomes. In: J.B. Halter, J. G. Ouslander, M. E. Tinetti, S. Studenski, K. P. High and S. Asthana (Eds), Hazzard's geriatric medicine and gerontology. Sixth Edition. Mc Graw Hill Medical, pp.431-437.

Gabeau, D., \& Rosenthal, R. A. (2001). Preoperative evaluation of the elderly surgical patient. In: R. A. Rosenthal, M. E. Zenilman, and M. R. Katlic (Eds), Principless and practice of geriatric surgery. First Edition. New York: Springer-Verlag, pp.126-143. 
Kalkan, N., \& Karadağ, A. (2017). Determining the functional autonomy level of preoperative elderly patients: A Turkish case study. Journal of Human Sciences, 14(3), 2827-2838. doi:10.14687/jhs.v14i3.4836

Hacıhasanoğlu, R., Yıldırım, A., \& Karakurt, P. (2012). Loneliness in elderly individuals, level of dependence in activities of daily living (ADL) and influential factors. Archives of Gerontology and Geriatrics, 54(1), 61-66. doi: 10.1016/j.archger.2011.03.011

Hacker, E. D., Zimmerman, S., \& Burgener, S. C. (2014). Measurement of quality of life outcomes. Research in Gerontological Nursing, 7(1), 7-12. doi: 10.3928/19404921-20131126-02.

Hébert, R., Guilbault, J., Desrosiers, J., \& Dubuc, N. (2001). The functional autonomy measurement system (smaf): a clinical-based instrument for measuring disabilities and handicaps in older people. Geriatrics Today, 141-147.

Kim, S., Brooks, A. K., \& Groban, L. (2015). Preoperative assessment of the older surgical patient: honing in on geriatric syndromes. Clinical Interventions in Aging, 10, 13-27. doi: 10.2147/CIA.S75285

King, M. B., Whipple, R. H., Gruman, C. A., Judge, J. O., Schmidt, J. A., \& Wolfson, L. I. (2002). The performance enhancement project: Improving physical performance in older persons. Archives of Physical Medicine and Rehabilitation, 83(8), 1060-1069.

Karabulut, N., \& Çetinkaya, F. (2011). Cerrahi kliniklerinde çalışan hemşirelerin hasta bakımında karşılaştıkları güçlükler ve motivasyon düzeyleri [Motivation levels and difficuilties encountered in the patient care of the nurses working in surgery clinics]. Journal of Anatolia Nursing and Health Sciences, 14(1), 14-23.

Mizokami, F., Koide, Y., Noro, T., \& Futura, K. (2012). Polypharmacy with common diseases in hospitalized elderly patients. The American Journal of Geriatric Pharmacotherapy, 10(2), 123-128. doi: 10.1016/j.amjopharm.2012.02.003

Monarch, S., \& Wren, K. (2004). Geriatric anesthesia implications. Journal of PeriAnesthesia Nursing, 19(6), 379-384.

Nascimento, C. M., Ribeiro, A. Q., Cotta, R. M. M., Acurcio, F. A., Peixoto, S. V., Priore, S. E., \& Franceschini S. C. (2012). Factors associated with functional ability in Brazilian elderly. Archives of Gerontology and Geriatrics, 54(2), e89-e94. doi: 10.1016/j.archger.2011.08.005

Olgun, N., Aslan, F. E., Yücel, N., Öntürk, Z. K., \& Laçin, Z. (2013). Yaşlıların sağlık durumlarının değerlendirilmesi [Assessment of health status of the elderly]. Acıbadem Üniversitesi Sağlık Bilimleri Dergisi, 4(2), 72-78.

Onem, Y., Terekeci, H., Küçükardalı, Y., Sahan, B., Solmazgül, E., Şenol, M.G., ... Oktenli, C. (2010). Albumin, hemoglobin, body mass index, cognitive and functional performance in elderly persons living in nursing homes. Archives of Gerontology and Geriatrics, 50(1), 56-59. doi: 10.1016/j.archger.2009.01.010

Özer, E., \& Özdemir L. (2009). Yaşlı bireyde akılcı ilaç kullanımı ve hemşirenin sorumlulukları [Rational drug usage in elderly and nurse's responsibilities]. Sağhk Bilimleri Fakültesi Hemsirelik Dergisi, 42-51.

Öztürk, A., Şimşek, T. T., Yümin, E. T., Sertel, M., \& Yümin, M. (2011). The relationship between physical, functional capacity and quality of life (QoL) among elderly people with a chronic disease. Archives of Gerontology and Geriatrics, 53(3), 278-283. doi: 10.1016/j.archger.2010.12.011

Öztürk, L., Erkılıç, E., Dal, H., Gümüş, T., \& Kanbak O. (2010). Altmış beş yaş ve üzeri ameliyat olan hastalarda cerrahi bölüm ve anestezi yöntemlerinin incelenmesi [A survey for the types of surgery and anesthetic methods in the patients aged 65 years and older]. Akademik Geriatri, 2, 40-44.

Tezcan, S., \& Seçkiner, P. (2012). Türkiye'de demografik değişim; yaşlllik perspektifi [The perspective of old age], D. Aslan and M. Ertem. (Eds). Yaşh sağglğı: sonuçlar ve çöqümler. First Edition. Palme, pp.1-8.

Totur, B., \& Korkmaz, D. (2011). Geriatrik cerrahide hasta bakım1 [Patient care in geriatric surgery]. Ege Üniversitesi Hemşirelik Yüksekokulu Dergisi, 27(2), 61-68. 
Kalkan, N., \& Karadağ, A. (2017). Determining the functional autonomy level of preoperative elderly patients: A Turkish case study. Journal of Human Sciences, 14(3), 2827-2838. doi:10.14687/jhs.v14i3.4836

Tuna, Z., \& Çelik S. Ş. (2014). Discharge training and counseling. Functional autonomy and postdischarge problems of elderly patients undergoing coronary artery bypass graft surgery. Turk Gogus Kalp Damar Cerrahisi Dergisi, 22(3), 1-7. doi: 10.5606/tgkdc.dergisi.2014.9623

Tuna, Z., \& Çelik, S. Ş. (2012). Otonomi değerlendirme ölçeği'nin 65 yaş ve üstü bireylerde geçerlilik-güvenirlik çalışması [The validity and reliability study of the "functional autonomy measurement system" among 65 years and over age group]. Hacettepe Üniversitesi Sağhk Bilimleri Fakültesi Hemșirelike Dergisi, 51-61.

Tunçay, S. U., Özdinçler, A. R., \& Erdinçler, D. S. (2011). Geriatrik hastalarda düşme risk faktörlerinin günlük yaşam aktiviteleri ve yaşam kalitesine etkisi [The effect of risk factors for falls on activities of daily living and quality of life in geriatric patients]. Turkish Journal of Geriatrics, 14(3), 245-252.

Türkiye İstatistik Kurumu Haber Bülteni (Turkish Statistical Institute). (2014, June). Istatistiklerle Yashlar (Statistics on the elderly), 2013. Retrieved from http://www.tuik.gov.tr/PreHaberBultenleri.do?id=16057

Ucuzal, M., \& Akyolcu, N. (2008). Yaşlı hastalarda ameliyat sonrası bilişsel değişiklikler [Postoperative cognitive changes in elderly]. Turkish Journal of Geriatrics, 11(3), 119-127.

Ulusel, B., Soyer, A., \& Uçku, R. (2004). Toplum içinde yaşayan yaşlilarda günlük yaşam etkinliklerinde bağımlllık düzeyi ve etkileyen risk etmenleri [Dependence in daily living activities among community dwelling elderly: prevelance and risk factors]. Turkish Journal of Geriatrics, 7(4), 199-205.

Varl, M., Aras, S. D., \& Atl1, T. (2009). Yaşlıda üriner inkontinans ve tedavisi [Urinary incontinence and treatment in the elderly]. Akademik Geriatri, 1, 45-58.

World Health Organization. (2002, April). Active aging a policy framework. Retrieved from http://apps.who.int/iris/bitstream/10665/67215/1/WHO NMH_NPH 02.8.pdf 